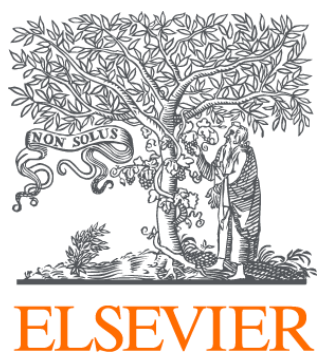

Since January 2020 Elsevier has created a COVID-19 resource centre with free information in English and Mandarin on the novel coronavirus COVID-

19. The COVID-19 resource centre is hosted on Elsevier Connect, the company's public news and information website.

Elsevier hereby grants permission to make all its COVID-19-related research that is available on the COVID-19 resource centre - including this research content - immediately available in PubMed Central and other publicly funded repositories, such as the WHO COVID database with rights for unrestricted research re-use and analyses in any form or by any means with acknowledgement of the original source. These permissions are granted for free by Elsevier for as long as the COVID-19 resource centre remains active. 


\title{
Influenza and Endemic Viral Pneumonia
}

\author{
Clare D. Ramsey, MD, MSc, FRCPC ${ }^{a, b, c, *}$, Anand Kumar, MD, FRCPC ${ }^{b}$
}

\section{KEYWORDS}

- 2009 H1N1 • Viral pneumonitis • Viral pneumonia • Influenza

- Acute respiratory distress syndrome • Acute lung injury

\section{KEY POINTS}

- Viruses are an important cause of community-acquired pneumonia in both pediatric and adult populations.

- Disease surveillance systems are important in detecting outbreaks and particularly the emergence of novel viral pathogens capable of human transmission.

- Several common viral pathogens can lead to severe respiratory disease, including the most common virus, influenza A.

- Treatment of viral pneumonia is generally supportive; however, diagnostic testing to isolate the causative virus is important because some pathogens, such as influenza virus, have effective antiviral therapies.

- In the case of $2009 \mathrm{H} 1 \mathrm{~N} 1$, early treatment with antiviral therapy appeared to be associated with improved outcomes.

\section{EPIDEMIOLOGY OF VIRAL PNEUMONIA}

Pneumonia is a common illness with estimates of approximately 450 million cases per year. According to the World Health Organization, lower respiratory tract infections account for approximately $7 \%$ of deaths per year worldwide. ${ }^{1}$ Viruses are a common cause of community-acquired pneumonia, particularly among children. Among pediatric community-acquired pneumonia studies, where viral causes were specifically sought, the incidence of viral etiology of infection was $49 \%$. The most common viruses isolated were respiratory syncytial virus (RSV) (11\%), influenza virus (10\%), parainfluenza virus (8\%), and adenovirus $(3 \%) .{ }^{2} \mathrm{~A}$ Canadian study found that among adults

Disclosures: The authors have nothing to disclose.

a Section of Respiratory Medicine, Department of Medicine, University of Manitoba, RS 314, 810 Sherbrook Street, Winnipeg, Manitoba R3A 1R8, Canada; ${ }^{b}$ Section of Critical Care, Department of Medicine, University of Manitoba, GC 425, 820 Sherbrook Street, Winnipeg, Manitoba R3T 2N2, Canada; ' Department of Community Health Sciences, University of Manitoba, S113, 750 Bannatyne Avenue, Winnipeg, Manitoba R3E OW3, Canada

* Corresponding author. RS 309, 810 Sherbrook Street, Winnipeg, Manitoba R3A 1R8, Canada.

E-mail address: cramsey@hsc.mb.ca 
hospitalized with community-acquired pneumonia with an identifiable pathogen, $15 \%$ were viral and $20 \%$ bacterial, with $4 \%$ being mixed. The most common viral pathogens were influenza, human metapneumovirus, and RSV. Patients with viral infections were older, more likely to have cardiac disease, and in general more frail compared with adults with bacterial pneumonia. Furthermore, all cases of viral pneumonia occurred between October and May, whereas bacterial pathogens had no seasonal predilection. In this study, there were no differences in outcomes between viral or bacterial causes of pneumonia. ${ }^{3}$ In a retrospective cohort analysis of adults admitted to an intensive care unit (ICU) with either severe community-acquired or health careassociated pneumonia, 115 of 198 patients had bronchoalveolar lavage and 159 of 198 had nasopharyngeal swabs for real-time polymerase chain reaction (RT-PCR). Of those with samples, $36.4 \%$ had a viral pathogen isolated and $35.9 \%$ had a bacterial pathogen isolated. Viral pathogens isolated in order of highest to lowest frequency were rhinovirus, parainfluenza virus, human metapneumovirus, influenza, and RSV. Again in this study, mortality was not different between bacterial and viral causes of pneumonia. ${ }^{4}$

This article focuses on viruses most commonly associated with severe communityacquired pneumonia, including those associated with recent epidemics.

\section{INFLUENZA VIRUS}

Influenza virus kills hundreds of thousands of people worldwide each year. In most cases, influenza infections are self-limited, mild illnesses lasting 4 to 5 days with predominantly upper airway symptoms. Among the most common severe complications and causes of death from influenza are viral pneumonia and/or secondary bacterial pneumonia. $^{5}$ In the absence of a pandemic, $11 \%$ to $19 \%$ of patients hospitalized with laboratory-confirmed influenza require treatment in the ICU. ${ }^{6-10}$ Complications and death from influenza occur most commonly among the elderly, the very young, and those with chronic medical conditions. Chronic lung disease is the most common comorbidity associated with influenza infection, followed by neurologic disease, hemato-oncologic disease, and cardiac disease. ${ }^{6}$ Risk factors for severe influenza complications are summarized in Table 1. A younger age of patients with critical illness is seen during pandemics, including the $2009 \mathrm{H} 1 \mathrm{~N} 1$. In the historic 1918 pandemic, there was unexplained excess mortality in persons aged 20 to 40 years, with most deaths attributable to secondary bronchopneumonia, influenza-related lung disease, and associated cyanosis and cardiac collapse. ${ }^{11}$ In the 1918 epidemic it was estimated that one-third of the world's population were infected with influenza, and the case-fatality rate was exceptionally high at greater than $2.5 \%$ in comparison with other pandemics. The number of deaths has been estimated to be at least 50 million. $^{12}$

Pulmonary syndromes associated with the 1957 to 1958 influenza pandemic include an acute rapidly progressive pneumonia caused by the influenza virus alone, or concomitant viral and bacterial pneumonia. ${ }^{13,14}$ The clinical course of patients with severe viral pneumonia was that of a rapid onset of severe progressive shortness of breath, tachypnea, cyanosis, and agitation caused by respiratory distress. A classic prodromal illness of high fever, chills, sore throat, aches, and dry nonproductive cough preceded the development of respiratory distress. Physical examination showed evidence of fever, respiratory distress, diffuse inspiratory crackles bilaterally, and occasional wheezes. Chest radiography (CXR) showed bilateral infiltrates similar to those in congestive heart failure (CHF) but without other clinical signs of volume overload. Although values of partial pressure of oxygen $\left(\mathrm{PaO}_{2}\right)$ are not provided, the low oxygen 


\begin{tabular}{|c|c|}
\hline \multicolumn{2}{|c|}{$\begin{array}{l}\text { Table } 1 \\
\text { Prognostic indicators and risk factors for severe influenza complications }\end{array}$} \\
\hline Risk Factor and Comorbidities & Comments \\
\hline Age $<5$ y & $\begin{array}{l}\text { Children }<2 \text { y and those with chronic } \\
\text { cardiopulmonary disease at greatest risk }\end{array}$ \\
\hline Age $>65$ y & $\begin{array}{l}\text { Poor vaccine response, poor host response to } \\
\text { influenza infection }\end{array}$ \\
\hline Chronic cardiopulmonary diseases & COPD, asthma, congestive heart failure \\
\hline $\begin{array}{l}\text { Metabolic disease and chronic } \\
\text { liver disease }\end{array}$ & $\begin{array}{l}\text { Diabetes mellitus and cirrhosis increase the risk of } \\
\text { influenza complications }\end{array}$ \\
\hline Chronic neurologic illness & $\begin{array}{l}\text { Neurocognitive and neuromuscular diseases } \\
\text { associated with increased complications }\end{array}$ \\
\hline Pregnancy & Particularly women in the third trimester \\
\hline Obesity & $\begin{array}{l}\text { BMI }>35 \mathrm{~kg} / \mathrm{m}^{2} \text { increased the risk of influenza } \\
\text { complications on the } 2009 \text { outbreak }\end{array}$ \\
\hline Hemoglobinopathy & Sickle-cell disease patients at increased risk \\
\hline Immunosuppression & $\begin{array}{l}\text { Glucocorticoids, chemotherapy, HIV, transplant } \\
\text { recipients at increased risk }\end{array}$ \\
\hline Children receiving salicylates & Increased risk of Reye syndrome \\
\hline $\begin{array}{l}\text { Aboriginal populations, poverty, } \\
\text { poor access to health care services }\end{array}$ & $\begin{array}{l}\text { Delayed treatment associated with increased risk of } \\
\text { influenza complications }\end{array}$ \\
\hline Secondary bacterial pneumonia & $\begin{array}{l}\text { Bacterial pneumonia associated with longer ICU and } \\
\text { hospital stays with more nosocomial } \\
\text { complications and a greater mortality rate }\end{array}$ \\
\hline
\end{tabular}

Abbreviations: BMI, body mass index; COPD, chronic obstructive pulmonary disease; HIV, human immunodeficiency virus; ICU, intensive care unit.

From Opal S, Kumar A. Influenza. In: Vincent JL, Abraham E, Kochanek P, et al, editors. Textbook of critical care. 6th edition. Philadelphia: Elsevier Saunders; 2011; with permission.

saturations on high-level oxygen, radiographic characteristics, and lack of CHF would fit the description of acute respiratory distress syndrome (ARDS) secondary to viral pneumonia, as seen with the $2009 \mathrm{H} 1 \mathrm{~N} 1$ pandemic.

Many believe that much of the excess mortality attributed to the 1918 influenza epidemic was related to secondary bacterial pneumonia with organisms such as Staphylococcus aureus and Streptococcus pneumoniae. ${ }^{5,15}$ This opinion is supported by autopsy studies reporting severe bronchopneumonia with an ARDS-like illness, and cultured bacteria associated with pneumonic lesions; however, in some cases there was no evidence of bacterial pneumonia. ${ }^{11,16,17}$ Good epidemiologic evidence supports the emergence of an antigenically novel influenza virus in 1918 with high virulence to which many younger people had never been exposed, which was likely a significant contributor to the high mortality rates in this younger age group. ${ }^{12}$ In addition to the complication of severe respiratory failure, influenza infection has been associated with central nervous system, cardiac, skeletal, renal, and hepatic complications. ${ }^{18}$

\section{INFLUENZA A 2009 H1N1}

In the spring of 2009, an outbreak attributed to a new viral pathogen, swine-origin influenza A (2009 H1N1), led to a significant number of cases of severe hypoxemic respiratory failure attributable to viral pneumonia. The outbreak began in the Southwestern 
United States and Mexico, with rapid spread throughout the rest of the United States, Canada, and then the rest of the world. This spread led the World Health Organization (WHO) to declare a phase-6 global pandemic alert on June 11, 2009. ${ }^{19}$

The number of patients requiring admission to an ICU for viral pneumonitis caused by $2009 \mathrm{H} 1 \mathrm{~N} 1$ infection was much larger than rates due to seasonal influenza. ${ }^{20}$ The increased incidence of critical illness, along with a high transmissibility rate and rapid increase in case numbers over a short period of time, created a significant stress on hospital resources in several countries, particularly in terms of ICU resources. ${ }^{20,21}$ The need for invasive ventilatory support in some relatively underresourced nations in the Western hemisphere reportedly exceeded ICU capacity (Farmer C, personal communication, 2010).

\section{Epidemiology and Risk Factors for Respiratory Failure Related to H1N1 2009}

Since the onset of the pandemic in March of 2009, more than 214 countries and communities reported cases of pandemic $2009 \mathrm{H} 1 \mathrm{~N} 1$ influenza, with more than 18,000 deaths. ${ }^{22}$ In Australian provinces, approximately $5 \%$ of the population developed H1N1-related illness, $0.3 \%$ of infected patients were hospitalized, and $20 \%$ of hospitalized patients required ICU care, very similar to the proportions reported by the Public Health Agency of Canada. ${ }^{23,24}$ During the pandemic in Argentina there were $1,390,566$ cases of influenza-like illness and of those, 14,034 were admitted to hospital and 617 (4.4\%) died as of January 2, 2010. ${ }^{25}$ In the United Kingdom 13\% of 2009 H1N1 patients, both adults and children, were admitted to either an ICU or highdependency unit, with a mortality rate of $5 \%$. Of those who died, $59 \%$ were previously healthy, and hospital mortality rate increased with increasing age. ${ }^{26}$ Overall the casefatality rate was low $(<0.5 \%)$, and lower than generally reported for seasonal influenza, although there is much variability in estimates. ${ }^{27-31}$

The viral epidemic was initially suspected after an increasing number of young patients in Mexico were hospitalized with severe and, not infrequently, fatal pneumonia. In a reported series of the initial 2155 cases of severe pneumonia in Mexico, Chowell and colleagues ${ }^{32}$ found that $87 \%$ of deaths and $71 \%$ of cases of severe pneumonia occurred in patients between ages of 5 and 59 years, which represented a significant shift in the age distribution of patients with severe disease or deaths from seasonal influenza. In Australia and New Zealand, 722 patients were admitted to an ICU within a 3-month period of time with confirmed $2009 \mathrm{H} 1 \mathrm{~N} 1$. The mean number of admissions for viral pneumonitis within the same period in the prior 4 years was $57 .^{33}$

Despite the young age of patients requiring ICU admission for respiratory failure, the highest death rate was among those older than 50 years. ${ }^{34-36}$ However, because in comparison with seasonal influenza, $2009 \mathrm{H} 1 \mathrm{~N} 1$ affected younger individuals, the number of years of life lost was substantial, estimated to be between 334,000 and 1973,000 years in the United States from May to December 2009. ${ }^{37}$

Among those requiring critical care in Canada, $67 \%$ were female with a mean age of 32 years. The majority of patients had at least 1 comorbidity, most commonly chronic lung disease (asthma, chronic obstructive pulmonary disease [COPD], bronchopulmonary dysplasia), obesity, hypertension, smoking, and diabetes. However, the majority did not have the kinds of major chronic organ failure typical of patients admitted to medical ICUs. The mean Acute Physiology and Chronic Health Evaluation II (APACHE II) score of ICU patients was 20, with major comorbidities present in $30 \% .^{21}$ Similar patient demographics were noted in other countries, and many are known risk factors for influenza infection. ${ }^{33,38,39}$ Indigenous persons from Australia and New Zealand, as well as Aboriginal Canadians (26\%), were overrepresented among those who were critical ill. ${ }^{21,33,40}$ Obesity, which interestingly has not been 
previously linked to complications of influenza, was a prominent risk factor for severe respiratory disease secondary to $2009 \mathrm{H} 1 \mathrm{~N} 1 .{ }^{21,26,33,35,38,40-42}$ Pregnancy is well described as a risk factor for complications from seasonal influenza; however, the number of critically ill pregnant women with $2009 \mathrm{H} 1 \mathrm{~N} 1$ pneumonitis was disproportionately large and led to excess mortality in this group. ${ }^{42-45}$ In Australia and New Zealand, pregnant women had a relative risk of 13.2 of requiring ICU admission for their illness in comparison with nonpregnant women of childbearing age. Sixty-nine percent of women required mechanical ventilation and $11 \%$ died, all with viral pneumonitis and ARDS. ${ }^{44}$ In California, 22\% of pregnant women infected by $2009 \mathrm{H} 1 \mathrm{~N} 1$ required ICU admission and $8 \%$ died, leading to an influenza-specific maternal mortality rate of 4.3 per 100,000 live births. ${ }^{46}$

Finally, factors associated with treatment were shown to correlate with severe disease. Canadian data showed that the interval from onset of symptoms to initiation of antiviral therapy or hospitalization was longer among patients with more severe disease (ICU admission or death), ${ }^{24,40}$ and this was also shown to be true among hospitalized patients in the United States. ${ }^{35,41}$ Observational studies of severe influenza $\mathrm{H} 1 \mathrm{~N} 1$ pneumonia suggest that early initiation of antiviral therapy is associated with improved outcomes. ${ }^{47}$

\section{Clinical Presentation and Diagnosis}

Although most cases of $2009 \mathrm{H} 1 \mathrm{~N} 1$ were mild and self-limited, there were a significant number of cases with severe hypoxemic respiratory failure. Five clinical presentations with $2009 \mathrm{H} 1 \mathrm{~N} 1$ were commonly noted: viral pneumonitis, exacerbations of asthma or COPD, exacerbations of other underlying disease (ie, CHF, chronic renal disease), secondary bacterial pneumonia, and croup/bronchiolitis in the pediatric population. The clinical presentation most frequently requiring ICU admission was that of viral pneumonitis, and most of these patients presented with rapidly progressive and refractory hypoxemia and bilateral alveolar infiltrates on CXR. Most of these patients fulfilled criteria for acute lung injury (ALI) or ARDS. ${ }^{25,48}$

Patients with viral pneumonitis and hypoxemic respiratory failure presented with symptoms of cough, dyspnea, and fever. These patients had rapidly progressive hypoxemia with high ventilatory demands, and in most case series greater than $70 \%$ to $80 \%$ of patients admitted to the ICU with this syndrome required mechanical ventilation. ${ }^{21,35,41,49-51}$ Patients who presented with severe respiratory illness were hospitalized within a median of 2 to 6 days from onset of symptoms, and most requiring ICU admission did so within 24 hours of hospital admission. ${ }^{21,25,39,41,49}$ In comparison with other causes of viral pneumonitis or seasonal influenza, an increased number of patients had gastrointestinal symptoms, typically diarrhea. ${ }^{35,41,52-55}$

The most common radiologic findings were bilateral patchy consolidation and/or ground-glass opacities, often worse in the lower lung zones (Fig. 1). ${ }^{56}$ Among those requiring ICU admission and ventilation, at least 3 out of 4 lung quadrants on CXR were most commonly involved. ${ }^{21,25,39,56}$ Computed tomography scans of the chest showed similar findings, with predominantly diffuse ground-glass infiltrates and consolidation. ${ }^{56}$

In Canada, ICU patients with $2009 \mathrm{H} 1 \mathrm{~N} 1$ pneumonitis had a mean $\mathrm{PaO}_{2} /$ fraction of inspired oxygen $\left(\mathrm{FiO}_{2}\right)$ on admission of $147 \mathrm{~mm} \mathrm{Hg}$, and this remained on average lower than 200 among those remaining in the ICU at day 14. Seventy-three percent of patients had ALI at the onset of critical illness. Additional oxygenation and ventilatory support measures were not infrequently used, including high-frequency oscillatory ventilation $(12 \%)$, nitric oxide $(14 \%)$, neuromuscular blockade $(30 \%)$, prone ventilation $(5 \%)$, and extracorporeal membrane oxygenation $(7 \%) .{ }^{21} \mathrm{~A}$ similar degree 


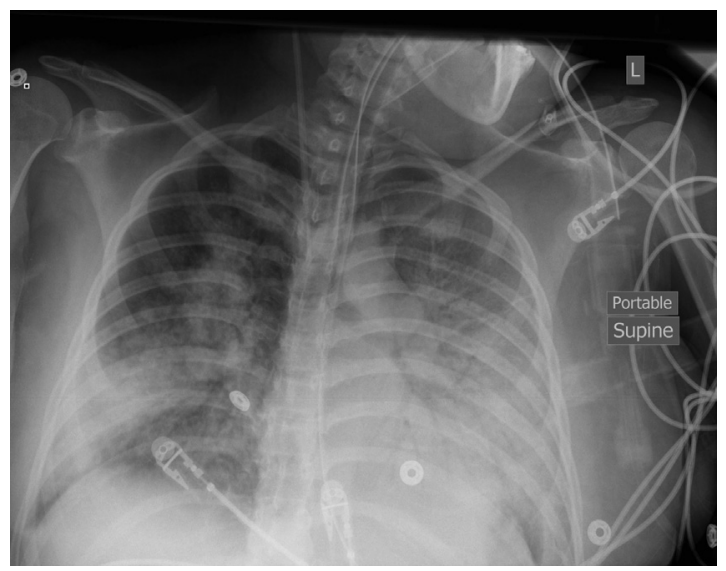

Fig. 1. Portable chest radiograph from a patient with H1N1 2009 viral pneumonitis and acute respiratory distress syndrome, showing diffuse bilateral airspace opacities.

of severe hypoxemia was noted in multiple case series from other countries. ${ }^{25,38,49,57}$ Thoracic compliance was noted to be decreased in a subset of patients with 2009 $\mathrm{H} 1 \mathrm{~N} 1-$ related hypoxemic respiratory failure, with a median of $22 \mathrm{~mL} / \mathrm{cm} \mathrm{H}_{2} \mathrm{O}$ (interquartile range $\left.21-34 \mathrm{~mL} / \mathrm{cm} \mathrm{H}_{2} \mathrm{O}\right){ }^{38}$ A significant number of patients developed at least 1 other organ dysfunction, and in some cases developed multisystem organ dysfunction. ${ }^{21,38,39}$

Duration of ventilation for $2009 \mathrm{H} 1 \mathrm{~N} 1$ varied, with an average (median or mean reported) of 7 to 18 days. ${ }^{21,38,51,52,58}$ The most common causes of death were severe ARDS with refractory hypoxemia and complications related to this, including infection, sepsis, or multisystem organ dysfunction. The most common infectious complication was secondary bacterial pneumonia, most frequently attributed to $S$ aureus or $S$ pneumoniae. ${ }^{21,35,59}$

Diagnosis of $2009 \mathrm{H} 1 \mathrm{~N} 12009$ pneumonitis is made based on the compatible clinical syndrome as already described, and the detection of the H1N1 influenza virus by RT-PCR and/or viral culture. Viral cultures take up to 1 week for processing and thus RT-PCR, typically on nasopharyngeal swabs, is the preferred technique. During the $2009 \mathrm{H} 1 \mathrm{~N} 1$ pandemic, it was noted that false-negative nasopharyngeal aspirates occurred in more than $10 \%$ of patients with viral pneumonitis. In severe cases of illness, tracheal aspirates or bronchoalveolar lavage specimens from intubated patients and repeated collection are recommended to increase the PCR diagnostic yield. ${ }^{23,29}$

\section{Pathophysiology}

Whether ARDS secondary to $2009 \mathrm{H} 1 \mathrm{~N} 1$ is related to direct damage from the virus or to the host's immune response to the virus is unclear. Pandemic $2009 \mathrm{H} 1 \mathrm{~N} 1$ virus can replicate in both the upper and the lower respiratory tract in comparison with seasonal influenza, which predominantly replicates in the upper respiratory tract. ${ }^{60-62}$ In a retrospective study from Hong Kong, To and colleagues ${ }^{63}$ examined the pattern of clinical disease, viral load, and immunologic profile between patients with varying severity of $2009 \mathrm{H} 1 \mathrm{~N} 1$. Those who died or had ARDS had delayed clearance of viral load in their nasopharynx, had higher levels of proinflammatory cytokines and chemokines, and higher likelihood of viremia. There was significant correlation between the levels of interleukin (IL-6, IL-10, and IL-15) and disease severity. The association between high IL-6 and severe disease from influenza has been previously established. ${ }^{64}$ Initial 
nasopharyngeal or endotracheal viral loads were similar among patients with differing disease severity; therefore, it would not appear to be viral load at the onset of infection that determines disease severity. ${ }^{63}$

\section{Pulmonary Pathology}

Most patients died of multisystem organ failure following admission for severe ARDS. On macroscopic examination, the lungs were noted to be heavy and diffusely edematous with areas of consolidation and hemorrhage. ${ }^{65}$ Lung pathology typically showed diffuse alveolar damage (DAD), at times with associated areas of hemorrhage and necrotizing bronchiolitis (Figs. 2 and 3 ).

In a report from the Centers for Disease Control and Prevention (CDC) the most frequent histopathology in the airways of patients with $2009 \mathrm{H} 1 \mathrm{~N} 1$ was inflammation and edema, with less frequent necrosis of the epithelium and hemorrhage. Lung tissue in all cases showed various stages of DAD, including edema, hyaline membranes, inflammation, and fibrosis. Seventeen patients had pulmonary thromboemboli. Immunohistochemistry showed viral antigens in airway epithelial cells, submucosal glands, and pneumocytes. ${ }^{66}$ Viral antigen was also commonly seen in alveolar macrophages. ${ }^{67}$ These studies show that $\mathrm{H} 1 \mathrm{~N} 12009$ virus has the ability to target both lower and upper respiratory tract infections, thus leading to DAD and clinical ARDS. Overall the pathologic findings were fairly similar to those published in autopsy studies from prior influenza epidemics in 1918 and 1957, including evidence of superimposed bacterial pneumonia. ${ }^{13,14,68,69}$

\section{Management of ARDS Secondary to H1N1}

Several studies examining risk factors for the development of ARDS related to 2009 $\mathrm{H} 1 \mathrm{~N} 1$ noted that time to treatment with antivirals was important: patients who received appropriate antiviral therapy with oseltamivir or zanamavir shortly after presentation for medical care had better outcomes. ${ }^{41,46,48}$ Rapid initiation of antivirals when $\mathrm{H} 1 \mathrm{~N} 1$ infection is suspected is particularly important in those with risk factors for disease progression and those requiring hospitalization. Ideally, therapy should be started within 48 hours of symptom onset, but is also effective and recommended if

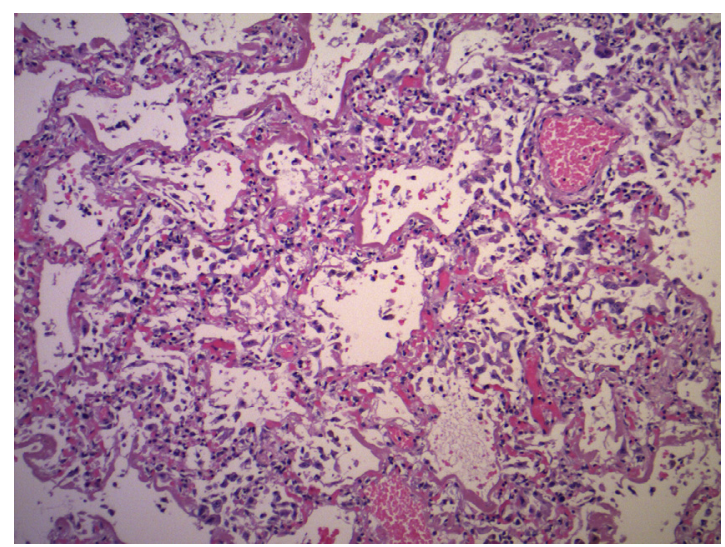

Fig. 2. Biopsy from a patient approximately 1 week into H1N1 2009 viral infection. This specimen demonstrates diffuse alveolar damage with hyaline membrane formation (hematoxylineosin, original magnification $\times 100$ ). (Courtesy of Dr Julianne Klein, MD, FRCPC, University of Manitoba, Winnipeg, Canada.) 


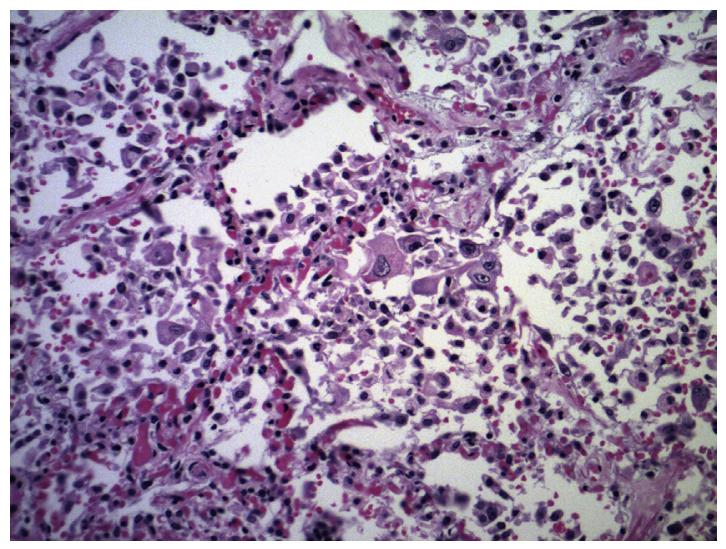

Fig. 3. Biopsy from patient with H1N1 2009 viral pneumonitis, demonstrating acute lung injury in the organizing phase. Type 2 pneumocyte hyperplasia and alveolar macrophages are prominent (hematoxylin-eosin, original magnification $\times 40$ ). (Courtesy of Dr Julianne Klein, MD, FRCPC, University of Manitoba, Winnipeg, Canada.)

given later than this. ${ }^{70}$ The recommended dose is $75 \mathrm{mg}$ twice a day, although higher doses were given at some centers for critically ill and obese patients according to WHO recommendations. ${ }^{71}$ Recent data suggest that $75 \mathrm{mg}$ of oseltamivir administered twice per day via the orogastric route in critically ill patients consistently yields sufficient blood levels for near maximal (in vitro) suppression of viral replication. ${ }^{72}$ Most patients also received broad-spectrum antimicrobial therapy, at least initially, while investigations were pending to determine the cause of respiratory failure. Current recommendations from the CDC state that antiviral treatment is recommended as early as possible in any patient with confirmed or suspected influenza who requires hospitalization, has severe, complicated, and progressive illness, or is at high risk for influenza complications (ie, <2 years and >65 years, immunocompromised, chronic disease, pregnant or postpartum, morbidly obese, Aboriginal, and residents of nursing homes or long-term care facilities). The current recommended therapy is either oseltamivir or inhaled zanamivir. However, in individuals with underlying respiratory disease, oseltamivir is recommended over zanamivir. ${ }^{73}$ In critically ill patients with pneumonia, the viral RNA may be detected in lower airway secretions for several weeks after the initiation of oseltamivir. In patients with influenza pneumonia or evidence of clinical progression, an increased dose of the oseltamivir (150 mg twice daily in adults) and, more importantly, an increased duration of therapy for 10 days instead of 5 days, may be warranted. ${ }^{29,74}$ Oseltamivir-resistant viruses have been isolated, but are not common. The resistance is via a His275Tyr mutation in viral neuraminidase, which confers high-level resistance to oseltamivir but not zanamivir. Most resistant isolates have been found in patients with prior oseltamivir exposure, and have been associated with mild self-limited disease. If oseltamivir resistance is suspected or confirmed, treatment should be with zanamivir. ${ }^{29,75}$

Most patients admitted to an ICU with $2009 \mathrm{H} 1 \mathrm{~N} 1$ viral pneumonitis fulfilled the criteria for ALI or ARDS and required mechanical ventilation. Many patients initiated on noninvasive positive-pressure ventilation (NIPPV) failed this mode, and subsequently required intubation and invasive ventilation. ${ }^{21,38}$ There are some reports of successful use of NIPPV, likely related to selection of less hypoxemic patients for this mode of treatment. ${ }^{25}$ Concerns arose regarding transmission of $\mathrm{H} 1 \mathrm{~N} 1$ with NIPPV, 
as this mode of ventilation generates respiratory droplets and aerosols, which can reach a $0.5-\mathrm{m}$ radius surrounding a patient receiving NIPPV. ${ }^{76}$

Most centers internationally ventilated $2009 \mathrm{H} 1 \mathrm{~N} 1$ viral pneumonitis patients with low tidal ventilation $(6 \mathrm{~mL} / \mathrm{kg}$ of predicted body weight and plateau pressures $<30 \mathrm{~cm} \mathrm{H}_{2} \mathrm{O}$ ) whenever possible, as this is what has been recommended for ARDS based on results of the ARDSNet trial. ${ }^{46,69,70,77-79}$ High levels of positive endexpiratory pressure (PEEP) were noted to be required to manage severe hypoxemia, with mean PEEP levels between 16 and $22 \mathrm{~cm} \mathrm{H}_{2} \mathrm{O}$ reported in some studies. ${ }^{25,38,39,49}$ Other modes of ventilation were also used, including airway pressure release ventilation and high-frequency oscillation; however, there are insufficient data to conclusively state whether these modes had any impact on outcomes. ${ }^{21,49}$ Similarly, recruitment maneuvers, prone positioning, and inhaled nitric oxide were used as salvage therapies for refractory hypoxemia, again with insufficient evidence to determine their effectiveness. ${ }^{21,25,49,80}$

Several studies have reported on the use of extracorporeal membrane oxygenation (ECMO) during the $2009 \mathrm{H} 1 \mathrm{~N} 1$ pandemic. The largest of these series is from Australia, where 68 patients with severe ARDS (median $\mathrm{PaO}_{2} / \mathrm{FiO}_{2}$ of 58 and PEEP of $18 \mathrm{~cm} \mathrm{H}_{2} \mathrm{O}$ ) were initiated on ECMO. Seventy-one percent survived their ICU admission and $21 \%$ died. By comparison, only 4 patients had been treated with ECMO for ARDS in the previous year in the same Australian centers. ${ }^{58}$ Reports from other countries on the use of ECMO for ARDS related to $\mathrm{H} 1 \mathrm{~N} 12009$ pneumonia are much smaller, with mortality rates of between $56 \%$ and $67 \% .{ }^{81,82}$

Avoidance of volume overload (and judicious diuresis) may also be associated with reduced duration of ventilation and length of stay in the ICU for most patients with ARDS. ${ }^{83}$ This strategy was used and recommended in patients with ARDS related to $2009 \mathrm{H} 1 \mathrm{~N} 1 .{ }^{84}$ Steroids were used in a variable number of patients across studies and for varying indications (sepsis, COPD or asthma exacerbation, stress-dose replacement therapy, or ARDS). ${ }^{21,41,52}$ One study in Argentina examined the effect of treatment with corticosteroids, and found steroids to be safe and associated with improvement in lung injury score. However, there were only 13 patients and there was no real comparator group, as all patients received some degree of steroid therapy. ${ }^{85}$ A study from the European Society of Intensive Care medicine H1N1 registry found that early use of corticosteroids in patients admitted to the ICU with H1N1 was associated with increased risk of superinfections, predominantly hospitalacquired pneumonia, with no mortality benefit. ${ }^{86}$ Similarly, other studies found no mortality benefit or even harm with early steroid use. ${ }^{87,88}$ At present there is insufficient evidence for routine use of steroids in $2009 \mathrm{H} 1 \mathrm{~N} 1$ or other influenza-related ARDS. Some historical data and experience with recent influenza epidemics suggests the potential utility of convalescent serum in the management of severe influenza. ${ }^{89,90}$ Although research on the issue is clearly required, the use of convalescent serum or immunoglobulin may become a useful treatment modality should future pandemic influenza A viruses be resistant to current antiviral agents.

\section{ADENOVIRUS}

Adenovirus is a common cause of mild upper respiratory illness in children; however, up to $20 \%$ of all children who are infected with adenovirus develop pneumonia. ${ }^{91}$ Among adults, adenovirus accounts for $1 \%$ to $7 \%$ of respiratory infections, particularly among immunocompromised adults and those in closed or crowed settings. ${ }^{91,92}$ Endemic cases occur throughout the year. In addition, epidemics have been reported among military recruits, long-term care facilities, and hospitals, with rapid spread of 
the virus. Adenovirus has also been shown to cause potentially fatal pneumonia, predominantly in immunocompromised hosts (especially transplant recipients). ${ }^{93} \mathrm{Symp}$ tomatology is similar to that of other viral pneumonias, with fever, cough preceded by upper respiratory symptoms, and bilateral interstitial infiltrates on CXR. In cases of severe adenoviral pneumonia, case-fatality rates are high and may be above $50 \%$.

Most cases of adenoviral pneumonia are due to serotypes $3,7,11$, or 14 . Transmission occurs via respiratory droplet secretions, tears, fecal-oral spread, or environmental surfaces. Infection-control measures are paramount in limiting disease spread. ${ }^{93,94}$ The incubation period ranges from 2 to 14 days. Infections of the respiratory tract can also be associated with gastrointestinal symptoms (gastroenteritis or diarrhea). Detection of the virus is through PCR, serologic testing, or viral culture. PCR has the highest sensitivity and specificity, whereas viral culture can be insensitive and take up to 21 days. ${ }^{91,95}$

The treatment of adenovirus infections is supportive for mild disease; there are no approved antiviral drugs. Although often used in severe cases, ribavirin (a guanosine analogue) has not been shown to be effective in small clinical studies. ${ }^{96}$ For immunocompromised patients and those with severe disease, cidofovir, a cytosine nucleotide analogue that inhibits DNA polymerase, has the greatest activity against the virus and is the preferred agent. ${ }^{97}$ Several nonrandomized studies in hematopoietic stem cell transplant recipients have shown a favorable response to this agent. ${ }^{98}$ Combination therapy with cidofovir and pooled intravenous immunoglobulin (IVIG) has been used, but data on the efficacy of this therapy are lacking. ${ }^{98}$

\section{Severe Acute Respiratory Syndrome and Other Coronaviruses}

The severe acute respiratory syndrome (SARS) coronavirus was first discovered in $2002 / 2003$ when an epidemic originating in Southern China spread rapidly (in a limited number of cases) to the rest of Asia and then Europe, Canada, and the United States. SARS is a highly contagious virus, with high rates of spread identified in health care workers. The case-fatality rate during the epidemic was $9.6 \%$ and was strongly associated with increasing age (case-fatality rate of $43.3 \%$ in those older than 60 years). ${ }^{99}$ SARS was noted to have multiple modes of transmission, including droplet and airborne spread as well as direct contact with contaminated surfaces. ${ }^{100,101}$ In the nosocomial cases, contaminated surfaces included surfaces in the patient's own rooms.

The clinical presentation of SARS is one of a prolonged influenza-like prodrome of fever, cough, chills, myalgias, dyspnea, and headache. As the infection progresses the respiratory symptoms are more profound, and up to $20 \%$ of patients required ICU admission and mechanical ventilation after a median of 8 days from symptom onset. ${ }^{102}$ The most common radiographic presentation was focal unilateral peripheral airspace disease, which progressed to multifocal unilateral or bilateral disease. ${ }^{103,104}$

Diagnosis is made based on clinical suspicion and contact with a known case, and is confirmed by either serologic testing or RT-PCR. RT-PCR for SARS has limited sensitivity and specificity, therefore repeated sampling is recommended. ${ }^{105}$ As with influenza, tracheal aspirates may be helpful in intubated patients with severe pneumonia. Serologic testing is the most sensitive test but it takes several weeks for antibodies to develop, with a mean time to seroconversion of approximately 18 to 20 days. ${ }^{106,107}$

Treatment of SARS is supportive, with little evidence of any effective antivirals or other pharmacologic therapies. ${ }^{108}$

A novel coronavirus was discovered in September 2012, which has now been referred to as the Middle East respiratory syndrome (MERS) coronavirus. As of May $31,2013,50$ cases have been confirmed with a death rate of $54 \%$. Most cases 
have occurred within the Arab Peninsula and neighboring countries. Infection with the novel coronavirus has led to severe lower respiratory tract illness. There is a low rate of human-to-human transmission; however, concern has arisen that the virus may adapt to being more efficient at such transmission. ${ }^{109}$

\section{Respiratory Syncytial Virus}

RSV is an enveloped RNA virus in the paramyxovirus family, which is primarily associated with fall to winter epidemics of lower respiratory illness in infants and young children. Up to $70 \%$ of newborns are infected during their first winter. RSV infection in adults generally represents reinfection, and may be the etiologic agent in up to $2.4 \%$ of community-acquired lower respiratory tract infections. ${ }^{110}$ Among the elderly, RSV infection is more common and may account for $10 \%$ of winter hospital admissions, with a case-fatality rate similar to that of influenza $(\sim 10 \%) .{ }^{111}$ Risk factors for severe disease are advanced age, immunocompromised state, and chronic cardiopulmonary diseases, for which higher death rates have been reported.

RSV lower respiratory tract infection in adults presents as a wheezing illness in $90 \%$ of cases, along with crackles and a pneumonic infiltrate in $40 \%$. However, the classic bronchiolitis picture seen in infants is rare in adult populations. Most adults present with nasal congestion, cough, and low-grade fever, which can be followed by dyspnea and wheezing. Often in adults the clinical features are difficult to distinguish from other respiratory viruses; however, myalgias and fever are less common, and wheezing and rhinorrhea more common, with RSV than with influenza infection. ${ }^{112} \mathrm{CXR}$ often demonstrates small focal infiltrates, but lobar infiltrates have been described. ${ }^{92}$ Diagnosis is best made by RT-PCR of nasal aspirates and, if available, lower respiratory sample (bronchoalveolar lavage or deep tracheal suctioning) or viral cultures, which are less sensitive.

The aerosolized form of ribavirin is approved for treatment of RSV in children. Data from adult populations are limited. Ribavirin has been used in immunocompromised adults with upper and lower respiratory tract infections, either alone or in combination with IVIG (standard or RSV-IVIG). ${ }^{113}$ Spread is via large droplets and fomites. Isolation and cohorting of infected patients is recommended.

\section{HUMAN METAPNEUMOVIRUS}

Human metapneumovirus (hMPV) is closely related to RSV, and primary infection often occurs in childhood; however, as with RSV, immunity is incomplete. In children the clinical manifestations are very similar to those of RSV. The incidence of symptomatic infection in adults is generally less than $5 \%$ in most studies. ${ }^{114}$

In a prospective study of hospitalized adults with cardiorespiratory illness during the winter season, hMPV was identified in $8.5 \%$ of the cohort. Of these patients, $13 \%$ and $12 \%$ required ICU admission and ventilatory support, respectively. The mortality rate overall was $7 \%$. Coinfection with RSV, coronavirus, and influenza A was noted in up to $23 \% .{ }^{115}$ hMPV can result in pneumonia and respiratory failure, although this is less common than with influenza and RSV. ${ }^{116}$ The clinical symptoms are indistinguishable from those of other respiratory viruses. Risk factors for severe disease are also similar to those for other viruses and include older age, immunocompromised state, and chronic cardiorespiratory disease. CXR reveals patchy infiltrates, predominantly in the lower lung zones. Identification of the virus optimally involves RT-PCR or direct immunofluorescence, as hMPV replicates very slowly and grows inefficiently using traditional viral culture methods. ${ }^{114}$ The mainstay of treatment, as with most viral infections, is supportive. A few case reports and series have reported ribavirin to be a 
potentially effective treatment, although more studies are needed before this can be recommended. ${ }^{117}$

\section{SUMMARY}

Viruses are an important cause of community-acquired pneumonia in both pediatric and adult populations. Viral pneumonias tend to have a seasonal predilection and are often preceded by a prodromal illness. Disease surveillance systems are important in detecting outbreaks and particularly the emergence of novel viral pathogens capable of human transmission. Several common viral pathogens can lead to severe respiratory disease, including the most common virus, influenza A. Unfortunately, appropriate diagnostic testing is often not pursued or is unavailable, particularly in smaller community hospitals. Treatment of viral pneumonia is generally supportive; however, diagnostic testing to isolate the causative virus is important because some pathogens, such as influenza virus, have effective antiviral therapies. Specifically in the case of $2009 \mathrm{H} 1 \mathrm{~N} 1$, early treatment with antiviral therapy appeared to be associated with improved outcomes.

\section{ACKNOWLEDGMENTS}

The authors would like to thank Dr Julianne Klein for providing pathology slides from patients with $\mathrm{H} 1 \mathrm{~N} 1$.

\section{REFERENCES}

1. The World Health Organization. The global burden of disease: 2004 update. Switzerland: Work Health Organization; 2008. Available at: http://www.who.int/ healthinfo/global_burden_disease/GBD_report_2004update_full.pdf. Accessed May 27, 2013.

2. Ruuskanen O, Lahti E, Jennings LC, et al. Viral pneumonia. Lancet 2011; 377(9773): 1264-75.

3. Johnstone J, Majumdar SR, Fox JD, et al. Viral infection in adults hospitalized with community-acquired pneumonia: prevalence, pathogens, and presentation. Chest 2008;134(6):1141-8.

4. Choi SH, Hong SB, Ko GB, et al. Viral infection in patients with severe pneumonia requiring intensive care unit admission. Am J Respir Crit Care Med 2012;186(4):325-32.

5. Khater F, Moorman JP. Complications of influenza. South Med J 2003;96(8): 740-3.

6. Coffin SE, Zaoutis TE, Rosenquist AB, et al. Incidence, complications, and risk factors for prolonged stay in children hospitalized with community-acquired influenza. Pediatrics 2007;119(4):740-8.

7. Moore DL, Vaudry W, Scheifele DW, et al. Surveillance for influenza admissions among children hospitalized in Canadian immunization monitoring program active centers, 2003-2004. Pediatrics 2006;118(3):e610-9.

8. Schrag SJ, Shay DK, Gershman K, et al. Multistate surveillance for laboratoryconfirmed, influenza-associated hospitalizations in children: 2003-2004. Pediatr Infect Dis J 2006;25(5):395-400.

9. Burton C, Vaudry W, Moore D, et al. Children hospitalized with influenza during the 2006-2007 season: a report from the Canadian Immunization Monitoring Program, Active (IMPACT). Can Commun Dis Rep 2008;34(12):17-32. 
10. Babcock HM, Merz LR, Fraser VJ. Is influenza an influenza-like illness? Clinical presentation of influenza in hospitalized patients. Infect Control Hosp Epidemiol 2006;27(3):266-70.

11. Morens DM, Taubenberger JK, Harvey HA, et al. The 1918 influenza pandemic: lessons for 2009 and the future. Crit Care Med 2010;38(Suppl 4):e10-20.

12. Taubenberger JK, Morens DM. 1918 Influenza: the mother of all pandemics. Emerg Infect Dis 2006;12(1):15-22.

13. Louria DB, Blumenfeld HL, Ellis JT, et al. Studies on influenza in the pandemic of 1957-1958. II. Pulmonary complications of influenza. J Clin Invest 1959; 38(1 Part 2):213-65.

14. Hers JF, Masurel N, Mulder J. Bacteriology and histopathology of the respiratory tract and lungs in fatal Asian influenza. Lancet 1958;2(7057):1141-3.

15. Brundage JF, Shanks GD. Deaths from bacterial pneumonia during 1918-19 influenza pandemic. Emerg Infect Dis 2008;14(8):1193-9.

16. Hirsch E, McKinney M. An epidemic of pneumococcus bronchopneumonia. $\mathrm{J}$ Infect Dis 1919;24:594-617.

17. French $\mathrm{H}$. The clinical features of the influenza epidemic of 1918-19. In: Great Britain Ministry of Health. Reports on public health and medical subjects. Report on the pandemic of influenza, 1918-19. London: His Majesty's Stationery Office; 1920. p. 66-109.

18. Bhat N, Wright JG, Broder KR, et al. Influenza-associated deaths among children in the United States, 2003-2004. N Engl J Med 2005;353(24):2559-67.

19. World Health Organization. World now at the start of 2009 influenza pandemic. Statement to the press by WHO director. Geneva (Switzerland): 2009 Available at: http://www.who.int/mediacentre/news/statements/2009/h1n1_pandemic_ phase6_20090611/en/index.html. Accessed May 27, 2013.

20. Kotsimbos T, Waterer G, Jenkins C, et al. Influenza A/H1N1_09: Australia and New Zealand's winter of discontent. Am J Respir Crit Care Med 2010;181(4): 300-6.

21. Kumar A, Zarychanski R, Pinto R, et al. Critically ill patients with 2009 influenza $\mathrm{A}(\mathrm{H} 1 \mathrm{N1})$ infection in Canada. JAMA 2009;302(17):1872-9.

22. Norfolk SG, Hollingsworth CL, Wolfe CR, et al. Rescue therapy in adult and pediatric patients with $\mathrm{pH} 1 \mathrm{~N} 1$ influenza infection: a tertiary center intensive care unit experience from April to October 2009. Crit Care Med 2010;38(11):2103-7.

23. Fowler RA, Jouvet $P$, Christian $M$, et al. Critical illness due to influenza A 2009 H1N1. Critical Care Rounds [Internet]. 2009 August 2010; October 2009: [1-12 pp.]. Available at: http://www.medtau.org/pandemic/ccrounds.pdf. Accessed April 15, 2013.

24. Campbell A, Rodin R, Kropp R, et al. Risk of severe outcomes among patients admitted to hospital with pandemic (H1N1) influenza. CMAJ 2010;182(4): 349-55.

25. Estenssoro E, Rios FG, Apezteguia C, et al. Pandemic 2009 influenza A in Argentina: a study of 337 patients on mechanical ventilation. Am J Respir Crit Care Med 2010;182(1):41-8.

26. Nguyen-Van-Tam JS, Openshaw PJ, Hashim A, et al. Risk factors for hospitalisation and poor outcome with pandemic A/H1N1 influenza: United Kingdom first wave (May-September 2009). Thorax 2010;65(7):645-51.

27. Fraser C, Donnelly CA, Cauchemez S, et al. Pandemic potential of a strain of influenza A (H1N1): early findings. Science 2009;324(5934):1557-61.

28. Wilson N, Baker MG. The emerging influenza pandemic: estimating the case fatality ratio. Euro Surveill 2009;14(26). 
29. Bautista E, Chotpitayasunondh T, Gao Z, et al. Clinical aspects of pandemic 2009 influenza A (H1N1) virus infection. N Engl J Med 2010;362(18):1708-19.

30. Presanis AM, De Angelis D, Hagy A, et al. The severity of pandemic H1N1 influenza in the United States, from April to July 2009: a Bayesian analysis. PLoS Med 2009;6(12):e1000207.

31. Hadler JL, Konty K, McVeigh KH, et al. Case fatality rates based on population estimates of influenza-like illness due to novel H1N1 influenza: New York City, May-June 2009. PLoS One 2010;5(7):e11677.

32. Chowell G, Bertozzi SM, Colchero MA, et al. Severe respiratory disease concurrent with the circulation of H1N1 influenza. N Engl J Med 2009;361(7):674-9.

33. Webb SA, Pettila V, Seppelt I, et al. Critical care services and 2009 H1N1 influenza in Australia and New Zealand. N Engl J Med 2009;361(20):1925-34.

34. Tuite AR, Greer AL, Whelan M, et al. Estimated epidemiologic parameters and morbidity associated with pandemic H1N1 influenza. CMAJ 2010;182(2):131-6.

35. Louie JK, Acosta M, Winter K, et al. Factors associated with death or hospitalization due to pandemic 2009 influenza $A(\mathrm{H} 1 \mathrm{~N} 1)$ infection in California. JAMA 2009;302(17):1896-902.

36. Gomez J, Munayco C, Arrasco J, et al. Pandemic influenza in a southern hemisphere setting: the experience in Peru from May to September, 2009. Euro Surveill 2009;14(42). pii:19371.

37. Viboud C, Miller M, Olson D, et al. Preliminary estimates of mortality and Years of life lost associated with the $2009 \mathrm{~A} / \mathrm{H} 1 \mathrm{~N} 1$ pandemic in the US and comparison with past influenza seasons. PLoS Curr 2010;2:RRN1153.

38. Miller RR 3rd, Markewitz BA, Rolfs RT, et al. Clinical findings and demographic factors associated with ICU admission in Utah due to novel 2009 influenza $\mathrm{A}(\mathrm{H} 1 \mathrm{N1}$ ) infection. Chest 2010;137(4):752-8.

39. Perez-Padilla R, de la Rosa-Zamboni D, Ponce de Leon S, et al. Pneumonia and respiratory failure from swine-origin influenza $A(H 1 N 1)$ in Mexico. N Engl J Med 2009;361(7):680-9.

40. Zarychanski R, Stuart TL, Kumar A, et al. Correlates of severe disease in patients with 2009 pandemic influenza (H1N1) virus infection. CMAJ 2010; 182(3):257-64.

41. Jain S, Kamimoto L, Bramley AM, et al. Hospitalized patients with 2009 H1N1 influenza in the United States, April-June 2009. N Engl J Med 2009;361(20): 1935-44.

42. Van Kerkhove MD, Vandemaele KA, Shinde V, et al. Risk factors for severe outcomes following 2009 influenza A (H1N1) infection: a global pooled analysis. PLoS Med 2011;8(7):e1001053.

43. Callaghan WM, Chu SY, Jamieson DJ. Deaths from seasonal influenza among pregnant women in the United States, 1998-2005. Obstet Gynecol 2010; 115(5):919-23.

44. Anzic Influenza Investigators. Critical illness due to 2009 A/H1N1 influenza in pregnant and post partum women: population based cohort study. BMJ 2010; 340:c1279.

45. Jamieson DJ, Honein MA, Rasmussen SA, et al. H1N1 2009 influenza virus infection during pregnancy in the USA. Lancet 2009;374(9688):451-8.

46. Louie JK, Acosta M, Jamieson DJ, et al. Severe 2009 H1N1 influenza in pregnant and postpartum women in California. N Engl J Med 2010;362(1):27-35.

47. Kumar A. Early versus late oseltamivir treatment in severely ill patients with 2009 pandemic influenza A (H1N1): speed is life. J Antimicrob Chemother 2011; 66(5):959-63. 
48. Bernard GR, Artigas A, Brigham KL, et al. The American-European Consensus Conference on ARDS. Definitions, mechanisms, relevant outcomes, and clinical trial coordination. Am J Respir Crit Care Med 1994;149(3 Pt 1):818-24.

49. Siau C, Law J, Tee A, et al. Severe refractory hypoxaemia in H1N1 (2009) intensive care patients: initial experience in an Asian regional hospital. Singapore Med J 2010;51(6):490-5.

50. Centers for Disease Control and Prevention (CDC). Hospitalized patients with novel influenza A (H1N1) virus infection-California, April-May, 2009. MMWR Morb Mortal Wkly Rep 2009;58(19):536-41.

51. Lum ME, McMillan AJ, Brook CW, et al. Impact of pandemic (H1N1) 2009 influenza on critical care capacity in Victoria. Med J Aust 2009;191(9):502-6.

52. Champunot R, Tanjatham S, Kerdsin A, et al. Impact of pandemic influenza (H1N1) virus-associated community-acquired pneumonia among adults in a tertiary hospital in Thailand. Jpn J Infect Dis 2010;63(4):251-6.

53. Dawood FS, Jain S, Finelli L, et al. Emergence of a novel swine-origin influenza $A$ (H1N1) virus in humans. N Engl J Med 2009;360(25):2605-15.

54. Human infection with new influenza $A(H 1 N 1)$ virus: clinical observations from Mexico and other affected countries, May 2009. Wkly Epidemiol Rec 2009; 84(21):185-9.

55. To KK, Wong SS, Li IW, et al. Concurrent comparison of epidemiology, clinical presentation and outcome between adult patients suffering from the pandemic influenza A (H1N1) 2009 virus and the seasonal influenza A virus infection. Postgrad Med J 2010;86(1019):515-21.

56. Agarwal PP, Cinti S, Kazerooni EA. Chest radiographic and CT findings in novel swine-origin influenza A (H1N1) virus (S-OIV) infection. Am J Roentgenol 2009; 193(6):1488-93.

57. Nin N, Soto L, Hurtado J, et al. Clinical characteristics and outcomes of patients with 2009 influenza $A(H 1 N 1)$ virus infection with respiratory failure requiring mechanical ventilation. J Crit Care 2011;26(2):186-92.

58. Davies A, Jones D, Bailey $M$, et al. Extracorporeal membrane oxygenation for 2009 influenza $A(H 1 N 1)$ acute respiratory distress syndrome. JAMA 2009; 302(17): 1888-95.

59. Muscedere J, Ofner M, Kumar A, et al. The occurrence and impact of bacterial organisms complicating critical care illness associated with influenza $A(\mathrm{H} 1 \mathrm{~N} 1)$ infection. Chest 2013;144(1):39-47.

60. Itoh $Y$, Shinya K, Kiso M, et al. In vitro and in vivo characterization of new swineorigin H1N1 influenza viruses. Nature 2009;460(7258):1021-5.

61. Munster VJ, de Wit E, van den Brand JM, et al. Pathogenesis and transmission of swine-origin 2009 A(H1N1) influenza virus in ferrets. Science 2009;325(5939): 481-3.

62. Maines TR, Jayaraman A, Belser JA, et al. Transmission and pathogenesis of swine-origin $2009 \mathrm{~A}(\mathrm{H} 1 \mathrm{~N} 1)$ influenza viruses in ferrets and mice. Science 2009;325(5939):484-7.

63. To KK, Hung IF, Li IW, et al. Delayed clearance of viral load and marked cytokine activation in severe cases of pandemic H1N1 2009 influenza virus infection. Clin Infect Dis 2010;50(6):850-9.

64. de Jong MD, Bach VC, Phan TQ, et al. Fatal avian influenza A (H5N1) in a child presenting with diarrhea followed by coma. N Engl J Med 2005;352(7): 686-91.

65. Mauad T, Hajjar LA, Callegari GD, et al. Lung pathology in fatal novel human influenza A (H1N1) infection. Am J Respir Crit Care Med 2010;181(1):72-9. 
66. Shieh WJ, Blau DM, Denison AM, et al. 2009 pandemic influenza A (H1N1): pathology and pathogenesis of 100 fatal cases in the United States. Am J Pathol 2010;177(1):166-75.

67. Gill JR, Sheng ZM, Ely SF, et al. Pulmonary pathologic findings of fatal 2009 pandemic influenza A/H1N1 viral infections. Arch Pathol Lab Med 2010; 134(2):235-43.

68. Lindsay MI Jr, Herrmann EC Jr, Morrow GW, et al. Hong Kong influenza: clinical, microbiologic, and pathologic features in 127 cases. JAMA 1970;214(10): 1825-32.

69. Ng WF, To KF, Lam WW, et al. The comparative pathology of severe acute respiratory syndrome and avian influenza A subtype H5N1-a review. Hum Pathol 2006;37(4):381-90.

70. Dominguez-Cherit G, Lapinsky SE, Macias AE, et al. Critically ill patients with 2009 influenza $A(H 1 N 1)$ in Mexico. JAMA 2009;302(17):1880-7.

71. World Health Organization. Clinical management of human infection with pandemic (H1N1) 2009: revised guidance. 2009 [cited 2010 September 3]. Available at: http://www.who.int/csr/resources/publications/swineflu/clinical_ management. Accessed June 10, 2013.

72. Ariano RE, Sitar DS, Zelenitsky SA, et al. Enteric absorption and pharmacokinetics of oseltamivir in critically ill patients with pandemic $(\mathrm{H} 1 \mathrm{~N} 1)$ influenza. CMAJ 2010;182(4):357-63.

73. Centers for Disease Control and Prevention. Updated interim recommendations for the use of antiviral medication in the treatment and prevention of influenza for the 2009-2010 season. 2009. Available at: http://www.cdc.gov/h1n1flu/ recommendations.htm. Accessed June 10, 2013.

74. World Health Organization. WHO guidelines for pharmacologic management of pandemic influenza A (H1N1) 2009 and other influenza viruses 2010 June 14, 2013. Available at: http://www.who.int/csr/resources/publications/swineflu/h1n1_ guidelines_pharmaceutical_mngt.pdf. Accessed June 10, 2013.

75. Update on oseltamivir-resistant pandemic A (H1N1) 2009 influenza virus. Wkly Epidemiol Rec 2009;85:37-40.

76. Hui DS, Hall SD, Chan MT, et al. Noninvasive positive-pressure ventilation: an experimental model to assess air and particle dispersion. Chest 2006;130(3): 730-40.

77. Kaufman MA, Duke GJ, McGain F, et al. Life-threatening respiratory failure from H1N1 influenza 09 (human swine influenza). Med J Aust 2009;191(3):154-6.

78. Ventilation with lower tidal volumes as compared with traditional tidal volumes for acute lung injury and the acute respiratory distress syndrome. The Acute Respiratory Distress Syndrome Network. N Engl J Med 2000;342(18):1301-8.

79. Ramsey C, Kumar A. H1N1: viral pneumonia as a cause of acute respiratory distress syndrome. Curr Opin Crit Care 2011;17:64-71.

80. Funk DJ, Kumar A. Inhaled nitric oxide in patients with the acute respiratory distress syndrome secondary to the 2009 influenza $A(H 1 N 1)$ infection in Canada. Can J Anaesth 2013;60(2):212-3.

81. Roch A, Lepaul-Ercole R, Grisoli D, et al. Extracorporeal membrane oxygenation for severe influenza $A(H 1 N 1)$ acute respiratory distress syndrome: a prospective observational comparative study. Intensive Care Med 2010;36(11): 1899-905.

82. Freed DH, Henzler D, White $\mathrm{CW}$, et al. Extracorporeal lung support for patients who had severe respiratory failure secondary to influenza A (H1N1) 2009 infection in Canada. Can J Anaesth 2010;57(3):240-7. 
83. Wiedemann HP, Wheeler AP, Bernard GR. Comparison of two fluid-management strategies in acute lung injury. N Engl J Med 2006;354(24):2564-75.

84. Funk DJ, Siddiqui F, Wiebe K, et al. Practical lessons from the first outbreaks: clinical presentation, obstacles, and management strategies for severe pandemic (pH1N1) 2009 influenza pneumonitis. Crit Care Med 2010;38(Suppl 4):e30-7.

85. Quispe-Laime AM, Bracco JD, Barberio PA, et al. H1N1 influenza A virusassociated acute lung injury: response to combination oseltamivir and prolonged corticosteroid treatment. Intensive Care Med 2010;36(1):33-41.

86. Martin-Loeches I, Lisboa T, Rhodes A, et al. Use of early corticosteroid therapy on ICU admission in patients affected by severe pandemic ( $\mathrm{H} 1 \mathrm{~N} 1) \mathrm{v}$ influenza $\mathrm{A}$ infection. Intensive Care Med 2011;37(2):272-83.

87. Diaz E, Martin-Loeches I, Canadell L, et al. Corticosteroid therapy in patients with primary viral pneumonia due to pandemic (H1N1) 2009 influenza. J Infect 2012;64(3):311-8.

88. Brun-Buisson C, Richard JC, Mercat A, et al. Early corticosteroids in severe influenza $\mathrm{A} / \mathrm{H} 1 \mathrm{~N} 1$ pneumonia and acute respiratory distress syndrome. Am J Respir Crit Care Med 2011;183(9):1200-6.

89. Luke TC, Kilbane EM, Jackson JL, et al. Meta-analysis: convalescent blood products for Spanish influenza pneumonia: a future H5N1 treatment? Ann Intern Med 2006;145(8):599-609.

90. Zhou B, Zhong N, Guan Y. Treatment with convalescent plasma for influenza A (H5N1) infection. N Engl J Med 2007;357(14):1450-1.

91. Lynch JP 3rd, Fishbein M, Echavarria M. Adenovirus. Semin Respir Crit Care Med 2011;32(4):494-511.

92. Cesario TC. Viruses associated with pneumonia in adults. Clin Infect Dis 2012; 55(1):107-13.

93. Kojaoghlanian T, Flomenberg P, Horwitz MS. The impact of adenovirus infection on the immunocompromised host. Rev Med Virol 2003;13(3):155-71.

94. Russell KL, Broderick MP, Franklin SE, et al. Transmission dynamics and prospective environmental sampling of adenovirus in a military recruit setting. J Infect Dis 2006;194(7):877-85.

95. Terletskaia-Ladwig E, Leinmuller M, Schneider F, et al. Laboratory approaches to the diagnosis of adenovirus infection depending on clinical manifestations. Infection 2007;35(6):438-43.

96. Gavin PJ, Katz BZ. Intravenous ribavirin treatment for severe adenovirus disease in immunocompromised children. Pediatrics 2002;110(1 Pt 1):e9.

97. Ison MG. Adenovirus infections in transplant recipients. Clin Infect Dis 2006; 43(3):331-9.

98. Neofytos D, Ojha A, Mookerjee B, et al. Treatment of adenovirus disease in stem cell transplant recipients with cidofovir. Biol Blood Marrow Transplant 2007; 13(1):74-81.

99. Donnelly CA, Ghani AC, Leung GM, et al. Epidemiological determinants of spread of causal agent of severe acute respiratory syndrome in Hong Kong. Lancet 2003;361(9371):1761-6.

100. Poutanen SM, Low DE, Henry B, et al. Identification of severe acute respiratory syndrome in Canada. N Engl J Med 2003;348(20):1995-2005.

101. Booth TF, Kournikakis B, Bastien N, et al. Detection of airborne severe acute respiratory syndrome (SARS) coronavirus and environmental contamination in SARS outbreak units. J Infect Dis 2005;191(9):1472-7.

102. Christian MD, Poutanen SM, Loutfy MR, et al. Severe acute respiratory syndrome. Clin Infect Dis 2004;38(10):1420-7. 
103. Bitar R, Weiser WJ, Avendano M, et al. Chest radiographic manifestations of severe acute respiratory syndrome in health care workers: the Toronto experience. Am J Roentgenol 2004;182(1):45-8.

104. Wong KT, Antonio GE, Hui DS, et al. Severe acute respiratory syndrome: radiographic appearances and pattern of progression in 138 patients. Radiology 2003;228(2):401-6.

105. Yam WC, Chan KH, Poon LL, et al. Evaluation of reverse transcription-PCR assays for rapid diagnosis of severe acute respiratory syndrome associated with a novel coronavirus. J Clin Microbiol 2003;41(10):4521-4.

106. Chen X, Zhou B, Li M, et al. Serology of severe acute respiratory syndrome: implications for surveillance and outcome. J Infect Dis 2004;189(7):1158-63.

107. Peiris JS, Chu CM, Cheng VC, et al. Clinical progression and viral load in a community outbreak of coronavirus-associated SARS pneumonia: a prospective study. Lancet 2003;361(9371):1767-72.

108. Stockman LJ, Bellamy R, Garner P. SARS: systematic review of treatment effects. PLoS Med 2006;3(9):e343.

109. MERS-CoV summary and literature update as of May 2013. Global Alert Response [Internet]. 2013 June 13, 2013 [cited 2013 May 31]. Available at: http://www. who.int/csr/disease/coronavirus_infections/update_20130531/en/index.html. Accessed June 13, 2013.

110. Dowell SF, Anderson LJ, Gary HE Jr, et al. Respiratory syncytial virus is an important cause of community-acquired lower respiratory infection among hospitalized adults. J Infect Dis 1996;174(3):456-62.

111. Falsey AR, Cunningham $\mathrm{CK}$, Barker $\mathrm{WH}$, et al. Respiratory syncytial virus and influenza A infections in the hospitalized elderly. J Infect Dis 1995;172(2): 389-94.

112. Falsey AR. Respiratory syncytial virus infection in adults. Semin Respir Crit Care Med 2007;28(2):171-81.

113. Shah JN, Chemaly RF. Management of RSV infections in adult recipients of hematopoietic stem cell transplantation. Blood 2011;117(10):2755-63.

114. Falsey AR. Human metapneumovirus infection in adults. Pediatr Infect Dis $J$ 2008;27(Suppl 10):S80-3.

115. Walsh EE, Peterson DR, Falsey AR. Human metapneumovirus infections in adults: another piece of the puzzle. Arch Intern Med 2008;168(22):2489-96.

116. Carrat $F$, Leruez-Ville $M$, Tonnellier $M$, et al. A virologic survey of patients admitted to a critical care unit for acute cardiorespiratory failure. Intensive Care Med 2006;32(1):156-9.

117. Shahda S, Carlos WG, Kiel PJ, et al. The human metapneumovirus: a case series and review of the literature. Transpl Infect Dis 2011;13(3):324-8. 